Revista Iberoamericana, Vol. LXXVIII, Núm. 241, Octubre-Diciembre 2012, 805-818

\title{
VLADIMIRO MONTESINOS O LA SANTIDAD DEL OFIDIO EN GRANDES MIRADAS, DE ALONSO CUETO ${ }^{1}$
}

\author{
POR \\ José Manuel Camacho Delgado \\ Universidad de Sevilla
}

[Inca Yupanqui] Hizo en el Cuzco (para castigo de
malos y espantajo de buenos) carceles y prisiones de
tan extraño horror que sus vasallos [temblaban] con
sola la noticia que de sus estrañezas oyan contar. Hizo
en Sanga Cancha una mazmorra soterriza de tantas
puertas ambages, y rebueltas que casi quizo ymitar á la
morada de el Mino Tauro de Creta, y toda ella sembrada
de agudos pedernales, y poblado de animales fieros
metidos y mantenidos allí, para aumentar el espanto á
loshombres, ansi como eran Leones Tigres Osos, ypor el
suelo entre el pavimento de pedernales mucha cantidad
de sapos, y culebras, y biboras traido todo aquesto de
la tierra y Provincia de los Andes. Tal carcel como esta
era dada á los rebeldes ynobedientes, y traydores y el
que alli entrava brevemente era despedazado de los
animales ó empecido de las mortiferas ponzoñas que
alli estavan guardando en su poder la muerte
Miguel Cabello Valboa, Miscelánea Antártica
Soy entomólogo. Colecciono mariposas
John Fowles, El coleccionista

1. Hacia unA TEOLOGÍA DEL MAL

La violencia y la religión forman un extraño maridaje que afecta a todas las épocas y a todas las sociedades de forma vertical. Tal y como aparece representado en la

\footnotetext{
1 Quiero expresar mi agradecimiento a la Asociación Universitaria Iberoamericana de Postgrado (AUIP) que me permitió viajar a Lima en marzo de 2007 gracias a una beca de movilidad entre Universidades Latinoamericanas y Andaluzas.
} 
literatura veterotestamentaria, las sociedades tribales y primitivas debían sacrificar a los miembros de su propia comunidad, cuando no tenían esclavos o enemigos disponibles, para contentar a un dios implacable y castigador que exige continuamente pruebas de la obediencia y la subordinación de su pueblo. Estos primeros sacrificios humanos fueron sustituidos en el plano simbólico por sacrificios de animales; de esta forma, el ternero o el cordero pasó a ocupar el lugar que les correspondería a los "inocentes" o a los primogénitos de las familias, lo que vendría a poner de manifiesto no sólo la subordinación de los pueblos a sus dioses, sino también la crueldad con que estos ejercen su autoridad (Girard 1995). Es necesario, por tanto, introducir el concepto de “poder” para comprender en toda su complejidad el contexto en el que la religión utiliza la violencia para alcanzar sus fines, y la violencia, por su parte, se sirve del lenguaje religioso para dar una dimensión trascendental y escatológica a lo que constituye, en muchos casos, un inventario siniestro de perversiones. En este sentido, una novela tan importante en la literatura hispanoamericana como El Señor Presidente (1946) de Miguel Ángel Asturias, considerada como la obra fundacional de la novela de la dictadura y uno de los textos pioneros del realismo mágico, constituye un verdadero monumento verbal donde se han imbricado en un triángulo macabro el poder, la violencia y la religión. No es casual, por tanto, que Tohil, el dios maya-quiché de la guerra y el fuego al que representa el Señor Presidente en su moderna epifanía, no exija ejecuciones, sino sacrificios humanos. ${ }^{2}$ La inmediatez y el sinsentido de la violencia quedan fecundados por lo mediato y trascendental del ámbito religioso. La ejecución convertida en sacrificio deja de ser un accidente en la vida de los hombres para convertirse en un asunto crucial de los dioses y sus ministros.

Estas reflexiones previas pretenden enmarcar la importancia que el filtro religioso llega a tener en cierto tipo de literatura que se sumerge en el lado oscuro del poder, como ocurre en la novela de Asturias, en El otoño del patriarca de García Márquez o en La fiesta del chivo de Vargas Llosa (Camacho Delgado, “Verdugos”). También ocurre lo

2 El texto clave para esta interpretación mítica de El Señor Presidente se encuentra en el capítulo XXXVII, titulado "El baile de Tohil": "Tohil exigía sacrificios humanos. Las tribus trajeron a su presencia los mejores cazadores, los de la cerbatana erecta, los de las hondas de pita siempre cargadas. 'Y estos hombres, ¡qué!; ¿cazarán hombres?’, preguntó Tohil. ¡Re-tún-tún! ¡Re-tún-tún!..., retumbó bajo la tierra. ‘¡Como tú lo pides -respondieron las tribus-, con tal que nos devuelvas el fuego, tú, el Dador de Fuego, y que no se nos enfríe la carne, fritura de nuestros huesos, ni el aire, ni las uñas, ni la lengua, ni el pelo! ¡Con tal que no se nos siga muriendo la vida, aunque nos degollemos todos para que siga viviendo la muerte!' ‘¡Estoy contento!’, dijo Tohil. ¡Re-tún-tún! ¡Re-tún-tún!, retumbó bajo la tierra. ‘¡Estoy contento! Sobre hombres cazadores de hombres puedo asentar mi gobierno. No habrá ni verdadera muerte ni verdadera vida. ¡Que se me baile la jícara!’.

Y cada cazador-guerrero tomó una jícara, sin despegársela del aliento que le repellaba la cara, al compás del tún, del retumbo y el tún de los tumbos y el tún de las tumbas, que le bailaban los ojos a Tohil.

Cara de Ángel se despidió del Presidente después de aquella visión inexplicable” (Asturias 376, énfasis mío).

Revista Iberoamericana, Vol. LXXVIII, Núm. 241, Octubre-Diciembre 2012, $805-818$
ISSN 0034-9631 (Impreso) 
mismo en una "novela política" como Grandes miradas ${ }^{3}$ del escritor peruano Alonso Cueto, uno de los grandes cronistas del horror y la violencia que asolaron el país en la guerra sucia mantenida por el Estado y los grupos subversivos, entre 1980 y el 2000. En este sentido, Cueto no es sólo un excelente taquígrafo de su tiempo, recopilando sin remilgos y sin grandes aspavientos el verdadero catálogo de monstruosidades en que se convirtió la política peruana bajo el gobierno del dictador Alberto Fujimori y su mano derecha Vladimiro Montesinos (Camacho Delgado, “Alonso Cueto”); a él le debemos una novela importante, que debe ser tomada en consideración a la hora de estudiar las representaciones literarias de la violencia en el Perú de los últimos años.

En las siguientes páginas se analiza Grandes miradas como ejemplo de novela política desde diferentes filtros religiosos. En ella se describe el estado de corrupción implantado por el tándem gubernamental Montesinos-Fujimori, mediante la utilización de procedimientos emparentados con la literatura hagiográfica. Es por ello que en la novela hay una recreación de la violencia política a través de los elementos religiosos característicos de la literatura mística, utilizando arquetipos que proceden tanto de las vidas de los santos como de las narraciones de los mártires de la Iglesia. En este sentido, Vladimiro Montesinos, favorito del dictador Alberto Fujimori y personaje central de Grandes miradas, aparece perfilado no sólo como delfín político de un régimen corrupto e implacable con los derechos humanos, sino también como una criatura maligna y satánica, relacionada con el mundo de las tinieblas a través de su caracterización como un ofidio de la política.

\section{Guido Pazos. La hagiografía política de un juez A lo diVino}

Alonso Cueto tuvo muy presente la personalidad y circunstancias de la muerte del juez César Díaz Gutiérrez a la hora de crear a su personaje Guido Pazos en Grandes miradas, al punto que entró en contacto con la familia del difunto, visitó su casa, su dormitorio, su oficina, habló con la gente que le rodeaba, todo ello para certificar la extraña fisonomía de un juez incorruptible, que se había alzado como una bandera de la honradez ante las inmundicias políticas del gobierno de Fujimori. No obstante, en su construcción literaria Cueto apunta hacia más lejos, hacia la utilización de modelos procedentes de la literatura religiosa, especialmente de los arquetipos consagrados en la literatura hagiográfica (Coon 1997). En una novela donde la violencia y la religión tienen una importancia estructural, la caracterización de Guido Pazos como un juez a lo divino, siguiendo, al menos de lejos, el modelo de los caballeros andantes a lo divino, permite al escritor dibujar el perfil de Vladimiro Montesinos bajo el mismo prisma

3 Cito siempre la edición española publicada por la editorial Anagrama. Las cursivas enfáticas que aparecen en los textos citados son mías.

ISSN 0034-9631 (Impreso) 
religioso, siguiendo un recorrido semántico inverso. Frente a la santidad laica del juez, Montesinos aparece retratado como un "santo de las tinieblas", una criatura satánica y pestilente de los sumideros del poder, un ofidio de la alta política, o, como dice el narrador, “el ángel de una Anunciación maligna” (116).

Desde el principio de la novela Guido Pazos ocupa el lugar privilegiado de otros jueces de la vida real que han dignificado el ámbito jurídico, como ocurre con Baltasar Garzón en España o el juez Guzmán Tapia en el Chile pospinochetista. Convertido en una suerte de “Juez Campeador", Guido Pazos se presenta como un funcionario de carrera impermeable a la corrupción, enrocado en los valores innegociables que deben presidir la vida judicial, política y social del Perú más allá de los escombros del fujimorismo. El narrador lo caracteriza como "un caballero aterrizado en el Palacio de Justicia, un sacerdote sin cáliz, un santo sin aureola” (23) y su despacho es "el altar en el que Guido oficiaba la misa de su probidad todos los días” (Cataudella 23). El mismo personaje establece los vínculos entre el mundo religioso y jurídico cuando recuerda su pasado seminarista y la misión redentora que le empuja a estudiar la carrera de leyes con la paciencia de un picapedrero para llevar justicia a la propia justicia: “[...] imagínate que estoy estudiando a estas alturas, yo era seminarista en realidad, iba para cura pero me salí y aquí estoy, pues. Pasé de cura a abogado. Bueno, pero los curas y abogados en algo se parecen. Que siempre andan de negro y bien vestidos, ¿no?” (Cueto 25). Esta condición mesiánica de la justicia le lleva a concebir el ejercicio de la profesión como un campo de batalla contra el Mal, representado por esa corte de políticos corruptos y sin escrúpulos, capaces de confundir la "patria” con la “plata”. En este sentido, un “juzgado no es una oficina, un juez no es un trabajador así nomás, es un dios de los hechos, les da su valor, los hace significar algo, un juez es una brújula, alguien a quien los justos del mundo observan con esperanza” (26). Los ensimismamientos del personaje, el vigor con que se ejercita contra las maldades de los gobernantes, su sentido inquebrantable de la honestidad frente a las tentaciones del demonio político o la exaltación con que vive sus triunfos y derrotas recuerdan los éxtasis característicos de la literatura hagiográfica, tal y como aparece magníficamente descrito en el texto:

Tenía un defecto admirable. Era un maniático del bien. Un ángel con la espada ardiendo por la justicia. Su trabajo como juez le daba empleo a su idealismo. Estaba decidido a entregarse a una causa. Esa causa era la justicia, las coimas, las influencias, los arreglos lo enardecían como si fueran blasfemias pronunciadas frente a un devoto. Capaz de perderse en raptos de furia moral, llegaba al punto del jadeo y la piel tensa y el comienzo del grito hasta que inclinaba la cabeza en su regazo y pedía disculpas por su rabia. (26)

Siguiendo la historia del personaje real, Cueto reconstruye el mundo familiar del juez, los valores y virtudes que presiden su educación, el hogar entendido como un “campo de entrenamiento para la virtud” (45) y la familia como un altar donde se ofician

\footnotetext{
Revista Iberoamericana, Vol. LXXVIII, Núm. 241, Octubre-Diciembre 2012, 805-818 ISSN 0034-9631 (Impreso) ISSN 2154-4794 (Electrónico)
} 
los ritos más transcendentales del hombre. Su ejercicio de la profesión es entendida como un sacerdocio laico y la lucha contra la corrupción como una lucha contra al pecado. Nada de lo que hace carece de un sentido religioso: el mismo coche que sigue manteniendo desde su época de estudiante, la austeridad con que viste, la Biblia abierta que preside su casa y su despacho, la música sacra, especialmente de Haydn, que lo acompaña en los momentos de meditación o la resignación con que acepta su muerte, teniendo siempre presente la crucifixión de Jesucristo, lo acercan al modelo del santo, un santo laico que convierte el palimpsesto bíblico en un vademécum legislativo y el sermón religioso en un código jurídico. En definitiva, tal y como le propusieron en su infancia, la vocación por la justicia de los hombres, es un trasunto de la justicia divina, equiparando en el plano de la devoción al juez y al sacerdote:

Fue cuando el padre Luis fue al colegio esa mañana y habló de las vocaciones, cuando explicó que el sacerdocio era una búsqueda de los caminos del bien, un ángel de la tierra que ama a todos los hombres que reconoce la naturaleza sagrada del individuo. Lo sagrado, lo divino, lo cristiano: vive de acuerdo con tus principios, ayuda a tus semejantes, ofrécele un sufrimiento a Dios todos los días. La belleza es un principio, la bondad es un principio, la verdad es un principio, la alegría de servir a los enfermos, a los pobres, a los necesitados [... ] Las palabras abren surcos en una tierra largamente preparada, uno ha venido a este mundo a servir y no a ser servido, la felicidad ajena es la semilla del futuro. Dios no es una idea sino un sendero, es decir una conducta, una manera de estar con los demás, abrir el surco de la generosidad, sembrar en la tierra de la solidaridad, sólo somos hijos de Dios en la noche del mundo si tenemos encendida la antorcha de la compasión al prójimo. La fe es una causa, no una consecuencia [...] La iglesia era una extensión de su casa y el mundo era una extensión de la iglesia. (45-46)

En la elaboración del personaje Cueto ha sido muy cuidadoso a la hora de seleccionar todos los datos que contribuyen a crear esa atmósfera religiosa que preside la vida del incansable juez y son muchos los momentos en que el narrador registra ese compromiso del protagonista con la justicia, con la legalidad, con la honradez, entendidos estos conceptos como manifestaciones últimas de la virtud religiosa. El texto está salpicado de referencias religiosas que afectan, de una manera u otra, a todos los personajes. En el capítulo VI de la novela, Guido Pazos aparece acorralado por las continuas amenazas que vienen desde el gobierno, para que limpie los expedientes de los amigos de Montesinos. En ese momento decide entrar en una iglesia, que funciona como un rito purificador:

[...] el arco de la iglesia, la pila de agua, el frío de las gotas en la frente, se sienta frente al altar, se arrodilla en la tabla de madera. El gran silencio, la oscuridad es una malla, puede sumergirse allí, humedecer la madera, encerrarse en el silencio, protegerse bajo el altar, descargar la cara sobre las manos, la madera aplanada en las rodillas, Dios mío, Dios mío, el refugio final. (61)

Revista Iberoamericana, Vol. LXXVIII, Núm. 241, Octubre-Diciembre 2012, 805-818 
Siguiendo esta caracterización religiosa, para su novia Gabi, Guido era:

[...] un combatiente fervoroso de la guerra moral que había declarado [...] Era un forastero de la realidad. El mal era un bicho ajeno. El bien era una bandera desplegada en el pecho. Pero el coraje de Guido lo debilitaba, lo hacía vulnerable [... ] Su honestidad era el principio de su pasión, una estaca de hielo en un pecho ardiente. Guido ofrecía a Gabriela un pacto de confianza. Sostenía para ella los pilares de resistencia al tiempo: el orden, la decencia, la honestidad, el esfuerzo. (75)

Una vez muerto reconoce que "había sido el único bálsamo, el único dios en el eterno purgatorio de sus carencias, el único capaz de acogerla, el único que podía alzar la cara y edificarse frente a los saqueos del pasado" (121). Desde su formación religiosa, Gabi ve a su novio y a su padre como versiones modernas de una suerte de caballería andante a lo divino:

La resignación de su padre, la pureza moral de Guido, las virtudes de la decencia frente a la adversidad. Su padre y su novio, caballeros andantes de un castillo perdido. Los dos habían aceptado la vida como un campo de honor plagado de derrotas enaltecedoras [...] La virtud, la pureza, la cabeza en alto. Desde extremos opuestos, los dos se habían ofrecido a la muerte. Serían desterrados al olvido incierto de los recuerdos honrosos, su padre y Guido, cadáveres prematuros, insignias en el álbum moral de su soledad. No estaba con ellos sino con su herencia virtuosa. (217)

Y concluye: “ ¿ $\ldots$ un hombre vivo que la abrace en vez de un ángel muerto en la distancia?” (218). No obstante, frente a la bondad de estos dos hombres ejemplares, ella tiene la necesidad de destruir el mundo que le rodea: "Pero los fantasmas de ambos la inspiraban. Ángeles del bien, se habían entregado a la muerte, se habían inmolado, habían desaparecido. Iban a volver en ella como demonios" (218).

Las virtudes de Guido Pazos llegan a inquietar a su antagonista, Vladimiro Montesinos, que no termina de creerse que existan personas con esa dimensión humana y ética, lejos de los reclamos de las comisiones ilegales e invulnerables ante los cantos de sirena de la corrupción política: “¿Quién es ese juez Guido Pazos? ¿Por qué no le obedece? ¿Alguien sabe más de él, un periodista, otros jueces? Tiene que saber más: qué come, con quién se acuesta, qué viajes hizo, con qué se droga. Nada, nada, no tiene nada. ¿Quién es así?” (81). Otro personaje clave en el desenlace trágico de la obra, el subalterno y asistente del juez, llamado Artemio, se siente como otro Judas después de haberlo vendido a los verdugos de Montesinos. Con gran habilidad, Cueto cambia el punto de vista de la narración para ver al traidor desde los ojos de la víctima, lo que sirve para reforzar aún más la dimensión humana del juez:

Revista Iberoamericana, Vol. LXXVIII, Núm. 241, Octubre-Diciembre 2012, 805-818
ISSN 2154-4794 (Electrónico) 
[Guido Pazos] No se asombró tanto de la presencia de los intrusos como de la cara doblada de Artemio y sólo entonces comprendió cuánto estaba sufriendo por haberlo traicionado, por haber hecho que lo mataran, y de qué modo había esperado cumplir con ese día para tratar desde entonces de olvidarlo. Tuvo aún un resto de conciencia para pensar en lo que le habrían ofrecido a cambio. (89)

La caracterización religiosa del juez no desaprovecha siquiera los ritos de despedida característicos del entierro (“Todos se acercan, el ataúd es un objeto sagrado, un altar de culpas ajenas”, 104). No obstante, es en el momento de la ejecución donde el personaje completa de forma simbólica su recorrido por la literatura hagiográfica. Los tormentos físicos y psicológicos que padece contribuyen a reforzar el ideal de la santidad que marca el itinerario del personaje, equiparando en un plano simbólico su pasión por la justicia con la pasión de Cristo. En cierto sentido, los padecimientos sufridos por el juez recrean los infiernos terribles e inenarrables descritos en la literatura mística, en la mejor tradición de las pocilgas imaginadas por Francisco de Quevedo en Las Zahurdas de Plutón. Por estremecedor que pueda resultar, las torturas, las violaciones y las ejecuciones tienen un marcado valor literario, ${ }^{4}$ y sirven, en este caso, para convertir los últimos momentos de la vida de Guido Pazos en un via crucis, con toda su dimensión escatológica. Sin embargo, a diferencia del sentido purificador que podríamos atribuirle a esta carga religiosa que sostiene con empeño y entusiasmo como si fuera un caballero andante a lo divino, la peregrinatio del juez no conduce a la redención social de los hombres, sino a la denuncia de un país que se ha convertido en un esperpento de la civilización. El texto de la ejecución del personaje no es sólo un monumento verbal de la literatura política, también lo es de la literatura mística:

Mantuvo los ojos abiertos, tratando de mirar de frente a los dos hombres, no como un gesto de venganza tácita sino como un estímulo para mantener la lucidez del sacrificio y elegir la primera oración. Sabiendo que ésos eran los últimos segundos de su vida sin dolor, sintió una curiosidad sagrada. Estaba a punto de explorar la subordinación de su cuerpo a los fines superiores, un proceso que en otro tiempo había estado reservado a misioneros capturados. Debía inventar un resto de felicidad para darle la bienvenida a ese destino que lo iba a sancionar como a un siervo privilegiado de los ministerios de Dios. Cerró los ojos con la memoria suficiente para escoger el silencio de los susurros

4 Jean Franco considera que el tratamiento literario de estas "violaciones" contra el género humano difícilmente pueden resultar originales porque el autor puede deslizarse con cierta facilidad por el tratamiento banal del asunto, el voyerismo, la tentación sadomasoquista o caer en los tópicos característicos de un tema tan escabroso (305-336). En este caso y mediante la utilización del filtro religioso, Alonso Cueto ha conseguido darle un tratamiento original a un asunto tan controvertido y espinoso. Lo mismo podríamos decir de algunos pasajes de su obra La hora azul, con la que el escritor peruano ganó en España el Premio Herralde de Novela en el 2005.

Revista Iberoamericana, Vol. LXXVIII, Núm. 241, Octubre-Diciembre 2012, 805-818
ISSN 0034-9631 (Impreso) 2154-4794 (Electrónico) 
_“Ave María, Señora de la Misericordia”-que iban a protegerlo. Los tipos le cortaron la ropa, y empezaron a sacar las herramientas. No habían tenido la compasión de vendarlo pero él se sintió agradecido, pues quería seguir mirándolos para buscar en los ojos ajenos el reflejo anticipado de su futuro. Ellos también iban a morir. Su muerte no estaba lejos y sería más violenta y humillante y sorpresiva. Ellos no la adivinaban. Iban a morir algún día, quizás pronto, sin haber reconocido ni por un solo instante la extensión y la variedad y la bondad esenciales de la vida. Eran unos perros amaestrados en la rutina de la muerte [...] Quizá [Gabi] iba a pensar como él en lo que estaba ocurriendo como una ofrenda. La secreta victoria de ese momento era una consecuencia natural de sus actos. No podía arrepentirse de quien era, de quien sería siempre. Una tranquilidad fúnebre se apoderó de sus músculos [...] Otros jueces iban a reconocer en su cuerpo una inspiración a su causa. Quizás una esperanza parecida había hecho avanzar a Cristo dos mil años antes [...] El sacrificio no era un rito simbólico sino un ejercicio práctico, una contribución al buen destino del mundo. (89-90)

El personaje sabe que el final está próximo porque "estaba entrando en la soledad de la muerte" y uno de sus últimos pensamientos recrea "la sonrisa de Cristo”, mientras envía "un alarido de protesta hacia los cielos” (90). Con su muerte se completa el itinerario hagiográfico del personaje. Quien había vivido como un santo de la justicia muere como un mártir de la política (Delehaye).

\section{Vladimiro Montesinos, SIC SEMPER TYRANNIS}

Uno de los problemas que tuvo que resolver Alonso Cueto a la hora de construir el personaje de Vladimiro Montesinos fue el de no mutilar su visión literaria del personaje y su potencial imaginativo, pagando un tributo excesivo al positivismo de la realidad. En la ficcionalización de los hechos, el lector habrá visto con sorpresa la cantidad de veces que se hace referencia a los ofidios -símbolos del Mal por antonomasia-, a través de la mirada del personaje y las escamas de su piel, así como las continuas alusiones al mundo de los insectos que son utilizadas para caracterizar a los personajes de la novela.

Cueto da a conocer a Vladimiro Montesinos como si fuera "una revelación del subsuelo” (264), una criatura procedente de los círculos infernales, un genio del mal que ha sido capaz de dar una puntada más en el inmenso tapiz de las reglas políticas de Maquiavelo, convirtiendo su particular catálogo de perversiones en el vademécum gubernamental que debe presidir la vida política del Perú. El narrador presenta a Montesinos al comienzo de la novela, en el capítulo I, y a partir de entonces, por medio de unflash-back, va a reconstruir las circunstancias que han propiciado ese extraño encuentro entre el "favorito" de Fujimori y la novia doliente del juez asesinado, quien llega hasta allí para perpetrar su particular venganza. A través de los ojos de Gabi contemplamos a un personaje que tiene el “cráneo húmedo, las mejillas altas, los ojos secos de ofidio, la nariz afilada, la piel de escamas y puntos, el grosor de la sonrisa” (15). Esta misma

\footnotetext{
(3) Revista Iberoamericana, Vol. LXXVIII, Núm. 241, Octubre-Diciembre 2012, 805-818 ISSN 0034-9631 (Impreso) ISSN 2154-4794 (Electrónico)
} 
descripción aparece de nuevo en el capítulo XXII (264) en un caso muy particular de repetitio, que permite a Cueto un sistema de rotación de ciertas secuencias narrativas para multiplicar la tensión psicológica de la novela. Aunque son muchos los momentos en que aparece descrito el "delfín” de Fujimori, sobre todo en su dimensión monstruosa, lo que recuerda el modelo per species del biógrafo romano Suetonio al referirse a Calígula o Nerón, nos interesa de forma particular aquellos momentos en que el escritor, haciendo un alarde de virtuosismo técnico, retrata el mundo sórdido de Montesinos, desde el exterior hacia el interior, es decir, desde su fisonomía hasta su psicología, dejando para el lector un retrato verdaderamente espeluznante de su personalidad. De esta forma, al hablar del personaje, lo caracteriza como si fuera un reptil, o mejor, como si se tratara de una serpiente, dado el contexto religioso que estamos analizando: "Los ojos fijos, la piel escamosa, el cuello corto le dan un aspecto de ofidio sobrealimentado" (29). Esta particular "bestialización" del personaje supone una regresión al mundo animal (en este caso, al mundo de las alimañas), que se completa cuando en el mismo contexto de inmundicia se caracteriza su actividad gubernamental: "La miseria es su elemento. Nada en la miseria con la fluidez y la velocidad de un anfibio que finge salir ocasionalmente a la superficie. Se introduce en un pozo de agua sucia todos los días” (31).

Para construir al personaje Montesinos, Cueto utiliza un discurso que tiene doble sentido, contribuyendo así a la anfibología semántica y a la propia bipolaridad que presenta el personaje. De esta forma, cuando le preguntan a don Ramiro, jefe de Javier, por el doctor, éste contesta: “Un enviado de Dios” (73). Algo parecido responde Don Osmán, uno de los capos de la prensa oficial, cuyo periódico es un órgano de propaganda del régimen, cuando responde a su empleada Ángela:

Bueno, es un señor maravilloso. Un enviado del Señor en verdad, te digo. Un hombre que trabaja veinte horas diarias. Un enviado de Dios, no sé dónde estaríamos sin él. Mira cómo está Colombia con los guerrilleros metidos y en cambio nosotros aquí comiendo tan tranquilitos, pues. (214)

La propia Gabi, en su primer encuentro con el verdugo de su prometido, se sorprende por el aura maléfica, casi sobrenatural, que desprende el personaje:

Nunca lo había vista en persona. Su lentitud silenciosa, su camisa granate, su mirada lateral. La sombra de carne se agiganta en la pared como si fuera un santo que se le apareciera en una revelación para darle instrucciones sobre su conducta, el ángel de una Anunciación maligna. (116)

El sello luciferino del personaje tiene incluso connotaciones vampíricas, en la mejor tradición de la literatura gótica:

\footnotetext{
Revista Iberoamericana, Vol. LXXVIII, Núm. 241, Octubre-Diciembre 2012, 805-818 ISSN 0034-9631 (Impreso) 
Sí, ponerse un terno y salir y masticar la sangre de los que se quedaron atrás [...] El carro avanza, deja el enjambre de cámaras, una carroza funeraria ataviada con las galas de un carro oficial [...] Piensa que todos afuera están muertos. Él es el único vivo, el que ha sobrevivido a los cadáveres que almacena. (185-186)

Uno de los rasgos característicos de la literatura hagiográfica tiene que ver con la abnegación con que el santo se dedica en cuerpo y alma por mantener el reinado de la virtud, el imperio del bien, el orden establecido por la deidad rectora. De esta forma, la literatura mística ofrece un catálogo sorprendente de trabajadores incansables por el mantenimiento de un mundo religioso donde el mal es derrotado en todos sus frentes. Montesinos aparece caracterizado en la novela -conforme a los datos de la realidadcomo un trabajador incansable, capaz de ejercer un control absoluto sobre todas las teclas del poder, sin desfallecer, sin sentir la tentación del descanso, más allá de la relajación semifurtiva o los amores vertiginosos de las escapadas clandestinas (Bowen y Holligan). Lo dice don Osmán: "Un hombre que trabaja veinte horas diarias” (214). El propio personaje, cuando habla con Mati, su protectora, hace la siguiente confesión: “[...] yo trabajo tanto, estoy aquí todo el día, he renunciado a todo, trabajo veinte horas diarias” (83). Y lo mismo hace con Gabi, cuando ésta se muestra reacia a tener relaciones con él. Montesinos le expone las circunstancias que rodean su vida, contribuyendo así al mito del tirano que no descansa, lo que trae a la memoria el recuerdo de Pedro Zamora, el protagonista del cuento “El llano en llamas” de Juan Rulfo y el de otros personajes como Miguel Cara de Ángel en El Señor Presidente o el de José Ignacio Sáenz de la Barra en El otoño del patriarca de García Márquez (Camacho Delgado):

\begin{abstract}
Llevo una vida muy sacrificada. Vivo en el SIN. No tengo ni un ratito de descanso. Vivo allí. Es muy duro [...] un hombre como yo está muy solo, ¿y por qué estás solo? Porque trabajo en la solución de los problemas nacionales sin motivaciones políticas, solamente pensando en los destinos de la nación como país, o sea pensamos en los problemas de Estado y no en las políticas de la oposición, sólo pensamos en el país, nada más. Montesinos le había hablado mirándola de frente, tú seguramente has escuchado que me atacan, me insultan, me dicen de todo, pero yo no aspiro a nada, Gabriela, ¿te das cuenta? Yo no aspiro ni siquiera a ser congresista, o sea mi trabajo es un trabajo anónimo, y a veces me pongo a pensar, ¿sabes, Gabriela? Qué ganas de tanta vaina, al final yo me saco la mugre, ¿y para qué? Pero cuando piensas en el Perú, en los objetivos nacionales, alguien tiene que hacer ese trabajo [... . y no importan los sacrificios, mírame, Gabriela, ¿̇ú me ves como un hombre tan malo como dicen? (226-227)
\end{abstract}

No obstante, en la novela hispanoamericana contemporánea son muy frecuentes los casos en que el mundo religioso está visto al revés, desde el reverso, de tal forma que los ángeles son ángeles caídos, los santos, son santos de las tinieblas y el mundo parece presidido por las fuerzas del Mal. De ahí que el planteamiento argumental de la novela

Revista Iberoamericana, Vol. LXXVIII, Núm. 241, Octubre-Diciembre 2012, $805-818$
ISSN 0034-9631 (Impreso) 
entronque con uno de los grandes tópicos de la literatura medieval, el "mundo al revés”, tal y como lo formulara Ernst Robert Curtius en su monumental obra Literatura Europea y Edad Media Latina, señalando la importancia que tiene la inversión de valores en toda la cultura occidental. Tomando como punto de partida uno de los Carmina Burana, Curtius plantea el tópico como una queja contra el tiempo presente:

\begin{abstract}
Lo que sucede es que el mundo entero está al revés; los ciegos conducen a los ciegos, precipitándose todos al abismo; las aves vuelan antes de criar alas; el asno toca el laúd; los bueyes danzan; los ladrones se hacen militares; los Padres de la Iglesia, San Gregorio Magno, San Jerónimo, San Agustín, y el Padre de los monjes, San Benito, están en la taberna, ante el juez o en el mercado de carnes; a María ya no le gusta la vida contemplativa, ni a Marta la activa; Lía se ha tornado estéril, y Raquel legañosa; Catón visita la fonda; Lucrecia se hace prostituta. Lo que antes se censuraba ahora se alaba. El mundo está descarrilado. $(144)^{5}$
\end{abstract}

Esta imagen del mundo al revés no es exclusiva del Medievo. También tiene una enorme vigencia en las sociedades criminales que se desarrollaron a lo largo de la Edad Moderna, en Europa e Hispanoamérica, durante los siglos XV, XVI y xvII, y encuentra un caldo de cultivo excepcional en la novela hispanoamericana, a partir de los años cuarenta. Es por ello que el tándem Fujimori-Montesinos acaba construyendo una suerte de "antiestado", con un "antigobierno" presidido por los "antivalores" relacionados con la extorsión, la corrupción, la guerra sucia, el chantaje, las violación de los derechos humanos y un sinfín de tropelías, algunas de las cuales han sido analizadas en el Informe de la Comisión de la Verdad y la Reconciliación. ${ }^{6}$

Finalmente, para completar la caracterización religiosa de Montesinos es necesario analizar su obsesión por grabar la vida de sus víctimas reales o potenciales en una cinta de vídeo, tal y como ya registrara Luis Jochamowitz en su libro Vladimiro. Vida y tiempo de un corruptor con el que se abre la novela de Cueto. Los famosos "vladivídeos", como se les llamó en su momento, delatan no sólo una verdadera "telaraña” informativa sobre la corrupción durante el fujimontesinismo, sino también la presencia de una personalidad perturbada y delictiva, que se complace y goza con todo tipo de perversiones visuales, a las que el historiador del cine Román Gubern ha llamado, en uno de sus libros, Patologías de la imagen. Montesinos no sólo disfruta viendo las atrocidades que manda grabar, sino que incluso se excita sexualmente con las escenas explícitas donde se viola, se

5 Por su parte, Gilbert Durand considera que “[...] en la estructura mística hay una inversión completa de valores: lo que es inferior ocupa el lugar de lo superior, los primeros son los últimos, el poder de pulgarcito viene a escarnecer la fuerza del gigante y del ogro” (263).

6 Ver Hatun Willakuy. Versión abreviada del Informe Final de la Comisión de la Verdad y Reconciliación.

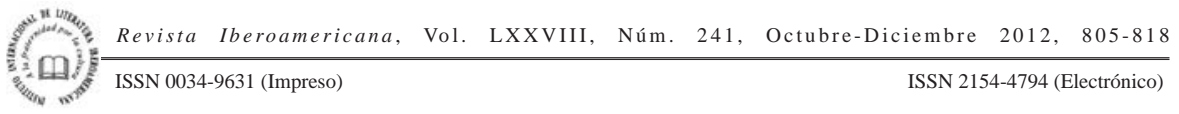


tortura o se asesina al adversario político, al periodista díscolo o al juez incorrupto. ${ }^{7}$ Se trata, en cierto sentido, de una variante del snuff cinema que, como escribe Gubern, es el "último estadio de la muerte violenta hecha espectáculo, que cuenta con una extensa y gloriosa tradición en la cultura occidental: gladiadores del Coliseo, ejecuciones públicas, tauromaquia, boxeo, etc. Con la ventaja de que el snuff cinema permite reproducir una y otra vez el placer del voyeur, gracias a la conservación de sus imágenes sobre un soporte" (La imagen 322-323).

El narrador recrea el placer del mirón que contempla el espectáculo del dolor y la muerte como si pudiera decidir sobre su continuidad o suspensión, como si pudiera gobernar sobre la vida de los hombres en un intento luciferino por escapar a los límites de la naturaleza y entrar en la jerarquía de los dioses. Eso es precisamente lo que hace Montesinos cuando apaga las luces de la sala y contempla a oscuras el horror que ha ordenado inmortalizar en la frialdad de la cinta de vídeo, sentirse como un demiurgo de la política, como un hacedor de la realidad, como un aprendiz de dios con resonancias borgeanas, que trata de corregir las imperfecciones de la vida con la perfección de las imágenes grabadas:

Montesinos enciende la pantalla, se mira entregando un fajo de billetes, se concentra en las cesiones en la casa del congresista que acepta el dinero.

El cuarto oscuro apenas se ilumina con la pantalla. La televisión es el sol de ese universo negro. Él es el centro de la televisión. Estira las piernas. La oscuridad del cuarto hace más ancha y profunda la mirada. La oscuridad es su hogar. Desde ese agujero puede ver pasar presidentes y ministros y asesores, todos reducidos por el fulgor de la vida pública. La grandeza de la oscuridad es suya. La luz descubre y vulnera, empequeñece los cuerpos. Él sabe, Vladi, que la verdadera vida es el secreto. Dios existe porque nadie lo ve. El que puede ver y no ser visto. Eso soy. No un hombre. Una fuerza, un rayo oscuro, permanente. Un ángel de humo blanco se confunde con la neblina. (257)

\footnotetext{
7 Son muchos los textos en los que vemos a un Montesinos extasiado y gozoso ante el dolor ajeno. Destacamos dos fragmentos que pueden resumir la patología del personaje:

a) “[... ] está despierto, se revuelve en la cama, manda llamar en Lima al encargado de manejar el VHS. El hombre llega a las tres. ¿Sí, doctor? Póngame esta cinta, le dice. Una cara de costado, el cuerpo estirado sobre la cama, Vladi se lleva el vaso de whisky a la boca, se pone una mano entre las piernas. Ve al hombre amarrado, toma un sorbo, siente la primera erección” (95).

b) "Los tiene a su merced en esa pantalla. Sus ojos son órganos sexuales que penetran en la mente y la piel ajenas, la cámara es la extensión del falo, la posesión es una operación vasta y detallada. Archiva los cuerpos, los cuelga en sus estantes, los casetes forman un cementerio personal de prendas humanas. Verlos, tocarlos, atesorarlos. El periodista con las putas. El juez amarrado agonizando. El ex presidente colombiano con un niño. Todo listo, doctor, la voz del coronel. ¿Y a Fujimori? ¿Lo tenía? ¿Era suficiente? A ver, ponga ese video, dice. Un temblor en la mano. La pantalla se enciende. Pare allí, le dice al hombre. Déjeme ver allí. La imagen congelada del presidente” (98-99).
}

\footnotetext{
(3) Revista Iberoamericana, Vol. LXXVIII, Núm. 241, Octubre-Diciembre 2012, 805-818 ISSN 0034-9631 (Impreso) ISSN 2154-4794 (Electrónico)
} 
En su condición de juez y fiscal de las vidas ajenas, Montesinos adopta el papel de criatura todopoderosa, con tintes sobrehumanos, que tiene que velar sin descanso para que nada cambie, como el gran ofidio que custodia los huevos de la serpiente. En esa realidad de pesadilla con resonancias sadianas que fue para muchos peruanos el fujimorismo, Alonso Cueto ha sabido recrear de forma magistral la violencia política del personaje a través del filtro religioso, transcendiendo su maldad más allá de su tiempo y de su espacio, para enraizarla en una dimensión mítica y ancestral, en la que los verdugos actuales encarnan la crueldad de los dioses implacables de otros tiempos.

\section{BiBLIOGRAFÍA}

Asturias, Miguel Ángel. El señor Presidente. Madrid: Cátedra, 1997.

Bowen, Sally y Jane Holligan. El espía imperfecto. La telaraña siniestra de Vladimiro Montesinos. Lima: Ediciones Peisa, 2003.

Camacho Delgado, José Manuel. "Verdugos, delfines y favoritos en la novela de la dictadura”. CARAVELLE. Cahiers du Monde Hispanique et Luso-Bresilien 81 (2003): 203-228.

“Alonso Cueto y la novela de las víctimas”. CARAVELLE. Cahiers du Monde Hispanique et Luso-Bresilien 86 (2006): 247-264.

"Aquiles en los Andes. El odio y sus máscaras en la narrativa peruana de la violencia”. El odio y el perdón en el Perú. Siglos XVI al XXI. Claudia Rosas Lauro, ed. Lima: Pontificia Universidad Católica del Perú, 2009. 295-316.

Cataudella, Quintino. «Vite di Santi e Romanzo». Letterature Comparate. Problemi e Metodo (Studi in onore di Ettore Paratore). Bolonia: Pátron Editore, 1981. 931-952.

Coon, Lynda L. Sacred Fictions. Holy Women and Hagiography in Late Antiquity. Pennsylvania: U of Pennsylvania P, 1997.

Cotler, Julio y Romeo Grompone. El fujimorismo. Ascenso y caída de un régimen autoritario. Lima: Instituto de Estudios Peruanos, 2000.

Cueto, Alonso. Grandes miradas. Barcelona: Anagrama, 2005.

Curtius, Ernst Robert. Literatura Europea y Edad Media Latina. México: F.C.E., 1984.

Degregori, Carlos Iván. Ayacucho 1969-1979. El surgimiento de Sendero Luminoso. Lima: Instituto de Estudios Peruanos, 1990.

Delehaye, Hippolyte. Les passions des martyrs et les genres littéraires. Bruselas: Societé des Bollandistes, 1966.

Durand, Gilbert. Las estructuras antropológicas de lo imaginario. Madrid: Taurus, 1982.

Franco, Jean. Decadencia y caída de la ciudad letrada. La literatura latinoamericana durante la guerra fría. Barcelona: Debate, 2003.

Geremek, Bronislaw. La estirpe de Caín. La imagen de los vagabundos y de los pobres en las literaturas europeas de los siglos XV al XVII. Madrid: Mondadori, 1990.

Revista Iberoamericana, Vol. LXXVIII, Núm. 241, Octubre-Diciembre 2012, 805-818
ISSN 2154-4794 (Electrónico) 
Girard, René. La violencia y lo sagrado. Barcelona: Anagrama, 1995.

Gubern, Román. Patologías de la imagen. Barcelona: Anagrama, 2004.

La imagen pornográfica yotras perversiones ópticas. Barcelona: Anagrama, 2005.

Hatun Willakuy. Versión abreviada del Informe Final de la Comisión de la Verdad y Reconciliación. Lima: Comisión de Entrega de la Comisión de la Verdad y Reconciliación, 2004.

Jochamowitz, Luis. Vladimiro. Vida y tiempo de un corruptor. Lima: Ediciones El Comercio, 2002.

Kohut, Karl. “Literatura peruana hoy: crisis y creación”. Literatura peruana hoy: crisisy creación. Karl Kohut y José Morales Saravia, eds. Frankfurt/Main-Madrid: Veuvert/ Iberoamericana, 1988. 11-20.

Rospigliosi, Fernando. Montesinos y las fuerzas armadas. Lima: Instituto de Estudios Peruanos, 2000.

Salazar, Diego, "Entrevista con Alonso Cueto”. <www.clubliteratura.clubcultura.com/ especiales/especial.php?espid=247>.

Tapia, Carlos. Las fuerzas Armadas y Sendero Luminoso. Dos estrategias y un final. Lima: Instituto de Estudios Peruanos, 1997.

Theidon, Kimberly. Entre prójimos. El conflicto armado interno y la política de la reconciliación en el Perú. Lima: Instituto de Estudios Peruanos, 2004.

Uceda, Ricardo. Muerte en el Pentagonito. Los cementerios secretos del Ejército Peruano. Bogotá: Planeta, 2004.

Vich, Víctor. El caníbal es el Otro. Violencia y cultura en el Perú contemporáneo. Lima: Instituto de Estudios Peruanos, 2002.

\footnotetext{
20vista Iberoamericana, Vol. LXXVIII, Núm. 241, Octubre-Diciembre 2012, 805-818 ISSN 0034-9631 (Impreso) 